Reprod. Nutr. Dévelop., 1981, 21 (1), 69-81.

\title{
Influence of diet and prolonged fasting on blood lipids, ketone bodies, glucose and insulin in adult sheep
}

\author{
par J.-Cl. BOUCHAT, Françoise DOIZÉ, R. PAQUAY \\ with the technical assistance of Marie-Antoinette BOUCKOMS and D. CLOOSTERMANS
}

Laboratoire de Physiologie Animale,

Facultés Universitaires Notre-Dame de la Paix, B-5000 Namur, Belgium.

Summary. In order to study changes in blood composition during feeding and prolonged fasting, six adult Suffolk ewes received three different diets during three periods of four weeks. Two intake levels (one and three times maintenance) and two roughage/concentrate ratios (100 and 14 p. 100 roughage) were compared according to a twofold latin square. Afterwards the animals were fasted for an 11-day period.

The concentration of free fatty acids in the blood decreased when concentrate was added to the diet and when energy intake level, insufficient to meet maintenance requirements, was increased to just sufficient and then to excessive. Blood lipid and lipoprotein composition was not influenced by a change in diet. Supplying concentrate instead of roughage produced increases in the proportions of stearic acid in the triglycerides and free fatty acids and of linoleic acid in the phospholipids and cholesteryl esters and decreases in the proportions of oleic acid in the free fatty acids and of oleic and palmitic acids in the triglycerides and cholesteryl esters. When increasing intake level, the proportion of linoleic acid in the phospholipids and cholesteryl esters was further increased. Increased insulinemia was also observed with concentrate intake, particularly when the concentrate was fed ad libitum.

Differences in blood composition resulting from the dietary treatments rapidly disappeared with fasting. After an initial decrease, blood ketone bodies increased and the $\beta$-hydroxybutyrate/acetoacetate (BHB/AA) ratio decreased. Glycemia decreased initially and then stabilized; the concentration of free fatty acids increased from the first day onwards and the proportion of free fatty acids in total blood lipids also increased. An increased proportion of oleic acid in the free fatty acids and triglycerides was compensated for by a decrease of saturated acids. A decrease in the level of polyunsaturated fatty acids in the phospholipids and cholesteryl esters was balanced by increased levels of saturated and oleic acids. The high density lipoprotein/low density lipoprotein ratio (HDL/LDL) decreased and insulinemia showed a strong decrease during the first day. Blood composition seemed to stabilize after-5-6 days of fasting, except for the ketone bodies which increased again after 10 days of the fast and for glycemia which increased after 5-6 days of the fast.

The influence of previous dietary treatment on changes in blood composition during fasting clearly depended on the body conformation of the animal.

When animals showed similar body conformation, no differences in the blood changes were observed during fasting. But when lean and fat animals were compared, extensive differences were found in the blood composition after the food was removed. 


\section{Introduction.}

In a previous paper (Bouchat, Doizé and Paquay, 1980) results have been presented on the effects of fasting on blood concentrations of ketone bodies, glycemia and free fatty acids, on plasma lipid and fatty acid composition and on the fecal and urinary nitrogen losses in adult sheep during two periods of eight days.

The results obtained needed fuller investigation. The effects of the nature (concentrate/roughage ratio) and the level of food consumed before fasting could not be investigated. Various blood components appeared to stabilize after 5-6 days of fast, but they could not be accurately defined during the 8-day tests. It was thus necessary to conduct a further series of fasting trials in adult ewes that had been exposed to different feed intakes for several weeks prior to fasting. The fasting period was also prolonged. In order to improve our knowledge of body fat mobilization during fasting, the blood composition during feeding periods preceding the fasting test was studied and the plasma lipids analyzed more thoroughly. Plasma insulin was also determined.

This paper reports the results of these investigations.

\section{Material and methods.}

Experimental design is given in table 1.

TABLE 1

Experimental design

\begin{tabular}{ccccc}
\hline Period & Dates & Diet 1 & Diet 2 & Diet 3 \\
\hline Preexperimental & 03.01-16.01.1979 & \multicolumn{3}{c}{ Preexperimental diet } \\
1 & $17.01-13.02 .1979$ & sheep 1 and 4 & sheep 3 and 5 & sheep 2 and 6 \\
2 & $14.02-13.03 .1979$ & sheep 2 and 3 & sheep 4 and 6 & sheep 1 and 5 \\
3 & $14.03-16.04 .1979$ & sheep 5 and 6 & sheep 1 and 2 sheep 3 and 4 \\
Fasting & $16.04-27.04 .1979$ & & \multicolumn{2}{c}{ Only water available }
\end{tabular}

Preexperimental diet : $400 \mathrm{~g}$ long pasture hay

$400 \mathrm{~g}$ concentrate mixłure

Diet $1: 1200 \mathrm{~g}$ pasture hay $(760 \pm 283 \mathrm{~g}$ eaten)

Diet $2: 100 \mathrm{~g}$ pasture hay $(99 \pm 4 \mathrm{~g}$ eaten)

$600 \mathrm{~g}$ concentrate mixture (completely eaten)

Diet $3: 300 \mathrm{~g}$ pasture hay $(179 \pm 111 \mathrm{~g}$ eaten $)$

$1800 \mathrm{~g}$ concentrate mixture $(1436 \pm 271 \mathrm{~g}$ eaten $)$

Six dry, non-gestating adult Suffolk ewes, at least 2 years old and of medium body condition (mean live-weight $55 \mathrm{~kg}$ ) were housed in metabolic cages. During a two week preexperimental period, they received the same preexperimental diet composed of $50 \mathrm{p}$. 100 roughage and 50 p. 100 concentrate which was sufficient to cover their energy maintenance requirements. Thereafter the animals were divided into three 
groups receiving alternatively and successively 3 experimental diets during 4-week periods. The diets included two different roughage/concentrate ratios (100 roughage : diet $1 ; 14$ roughage : diets 2 and 3 ) and the composition was such as to satisfy (intake level 1 , diets 1 and 2 ) and to exceed by threefold (intake level 3, diet 3) the energy maintenance requirements of the sheep.

Pasture hay given during the experimental feeding periods contained 89.6 p. 100 dry matter, 7.5 p. 100 protein, 1.5 p. 100 fat, 27.2 p. 100 crude fibre and 8.3 p. 100 mineral matter. The concentrate mixture was composed of 88.3 p. 100 dry matter, 13.8 p. 100 protein, 3.4 p. 100 fat, 3.2 p. 100 crude fibre. Mean fatty acid composition of total lipids in the concentrate mixture was 1 p. 100 myristic acid, 26 p. 100 palmitic acid, 2 p. 100 palmitoleic acid, 5 p. 100 stearic acid, 30 p. 100 oleic acid, 30 p. 100 linoleic acid and 6 p. 100 linolenic acid ; pasture hay analysis showed values of 1 p. 100 myristic acid, 30-33 p. 100 palmitic acid, 2 p. 100 palmitoleic acid, 3-4 p. 100 stearic acid, 6-13 p. 100 oleic acid, 19-24 p. 100 linoleic acid and 23-28 p. 100 linolenic acid.

Hay was given at 10 a. m., concentrate at $11.30 \mathrm{a} . \mathrm{m}$. and food refusals were weighed every day. The sheep were weighed every Thursday and Friday at $9.30 \mathrm{a}$. m. and blood samples were taken by jugular puncture every Wednesday at $8.45 \mathrm{a}$. $\mathrm{m}$. Blood was collected for blood lipid determination (free fatty acid concentration, total lipid composition, fatty acid composition of the free fatty acids, triglycerides, phospholipids and cholesteryl esters, lipoprotein composition) and insulin analysis.

After the experimental periods, the sheep were fasted for 11 days (16 to 27 April). Water only was available. On 16 April, the initial day of the fasting period, the daily meal was given at $7.30 \mathrm{a}$. m. and the refusals removed at 9. a.m. A first blood sample was taken when refusals were removed. Other blood samples were taken every day at 9 a. m. Ketone bodies and glucose contents were also determined during the fasting experimental periods. The sheep were weighed on 16, 18, 20, 22, 24 and 27 April at 9 a. m.

Analysis. - Each individual blood sample was analyzed. The methods used to analyze the food, measure blood ketone bodies, glucose and free fatty acid contents and determine blood lipid and fatty acid compositions were those described previously (Doizé, Bouchat and Paquay, 1979 ; Bouchat, Doizé and Paquay, 1980). The fatty acid composition of the food was determined by the same methods as blood fatty acids. The blood lipoprotein was separated by agarose gel electrophoresis (Noble, 1968) and its distribution measured by densitometry $(600 \mathrm{~nm})$. Insulin was assayed by a double antibody radioimmunoassay technique using ovine insulin as a standard and iodinated ovine insulin as the competitive binder (Morgan and Lazarow, 1963).

\section{Results.}

Food intake and body weight changes. - Experimental diets 1 and 3 were not completely eaten (see table 1) ; the actual mean intake levels for diets 1, 2 and 3 were 0.6, 1.0 and 2.3, respectively. Roughage percentage was 100,14 and 11 p. 100 .

Ignoring the changes observed during the first week of each experimental period, the sheep lost a mean of $71 \mathrm{~g}$ live weight daily when fed diet 1 and gained respectively 
TABLE 2

Blood composition during feeding periods

\begin{tabular}{|c|c|c|c|c|c|c|c|c|}
\hline & & \multicolumn{2}{|c|}{ Diet 1} & \multicolumn{2}{|c|}{ Diet 2} & \multicolumn{2}{|c|}{ Diet 3} & \multirow{2}{*}{$\begin{array}{c}\text { Variance } \\
\text { analysis } \\
\left({ }^{1}\right)\end{array}$} \\
\hline & & Mean & SD & Mean & SD & Mean & SD & \\
\hline Free fatty acid content & $\mathrm{mg} / 100 \mathrm{ml}$ & 13.88 & 6.06 & 7.85 & 3.24 & 5.73 & 3.93 & $* *$ \\
\hline \multicolumn{9}{|l|}{ Total blood lipid composition } \\
\hline $\begin{array}{l}\text { Free fatty acids } \ldots \ldots \ldots \ldots \\
\text { Triglycerides } \ldots \ldots \ldots \ldots \ldots \\
\text { Phospholipids } \ldots \ldots \ldots \ldots \\
\text { Free Cholesterol } \ldots \ldots \ldots \ldots \\
\text { Cholesteryl esters } \ldots \ldots \ldots \ldots\end{array}$ & $\begin{aligned} \text { p. } 100 & \left({ }^{2}\right) \\
= & \left({ }^{2}\right) \\
-\quad & \left({ }^{2}\right) \\
-\quad & \left({ }^{2}\right) \\
- & \left({ }^{2}\right)\end{aligned}$ & $\begin{array}{l}18.71 \\
13.26 \\
28.54 \\
14.87 \\
24.70\end{array}$ & $\begin{array}{l}1.93 \\
3.70 \\
2.34 \\
2.33 \\
1.86\end{array}$ & $\begin{array}{l}17.60 \\
15.31 \\
29.09 \\
13.22 \\
24.82\end{array}$ & $\begin{array}{l}1.28 \\
2.01 \\
1.76 \\
1.72 \\
1.80\end{array}$ & $\begin{array}{l}17.93 \\
14.22 \\
28.51 \\
13.39 \\
25.97\end{array}$ & $\begin{array}{l}1.11 \\
1.39 \\
1.66 \\
1.63 \\
1.49\end{array}$ & $\begin{array}{l}\text { NS } \\
\text { NS } \\
\text { NS } \\
\text { NS } \\
\text { NS }\end{array}$ \\
\hline \multicolumn{9}{|l|}{ Blood lipoprotein composition } \\
\hline $\begin{array}{l}\text { Low density lipop............. } \\
\text { High density lipop. . }\end{array}$ & $\begin{array}{l}\text { p. } 100\left({ }^{3}\right) \\
\text { p. } 100\left({ }^{3}\right)\end{array}$ & $\begin{array}{l}41.17 \\
61.28\end{array}$ & $\begin{array}{l}8.89 \\
8.98\end{array}$ & $\begin{array}{l}40.11 \\
62.28\end{array}$ & $\begin{array}{l}7.91 \\
8.70\end{array}$ & $\begin{array}{l}40.22 \\
63.00\end{array}$ & $\begin{array}{l}8.31 \\
9.88\end{array}$ & $\begin{array}{l}\text { NS } \\
\text { NS }\end{array}$ \\
\hline \multicolumn{9}{|l|}{ Free fatty acid composition } \\
\hline 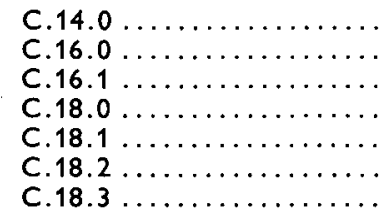 & $\begin{array}{l}\text { p. } 100\left(^{4}\right) \\
= \\
= \\
=\end{array}$ & $\begin{array}{r}1.41 \\
25.04 \\
2.49 \\
27.83 \\
38.95 \\
4.27 \\
0.00\end{array}$ & $\begin{array}{l}0.54 \\
3.11 \\
0.89 \\
6.43 \\
7.13 \\
1.94 \\
0.00\end{array}$ & $\begin{array}{r}1.52 \\
25.16 \\
2.34 \\
33.37 \\
32.52 \\
5.06 \\
0.00\end{array}$ & $\begin{array}{l}0.46 \\
3.46 \\
1.23 \\
5.48 \\
6.37 \\
2.55 \\
0.00\end{array}$ & $\begin{array}{r}1.90 \\
27.51 \\
3.81 \\
29.44 \\
30.49 \\
6.80 \\
0.00\end{array}$ & $\begin{array}{l}0.83 \\
5.35 \\
2.02 \\
7.17 \\
6.14 \\
4.01 \\
0.00\end{array}$ & $\begin{array}{c}\text { NS } \\
\text { NS } \\
\text { NS } \\
\text { NS } \\
* \\
* \\
\text { NS }\end{array}$ \\
\hline \multicolumn{9}{|l|}{ Triglyceride composition } \\
\hline 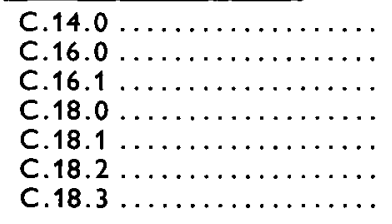 & $\begin{array}{l}\text { p. } 100\left(^{(5)}\right. \\
= \\
= \\
= \\
=\end{array}$ & $\begin{array}{r}1.77 \\
28.23 \\
3.01 \\
27.53 \\
34.63 \\
5.45 \\
0.27\end{array}$ & $\begin{array}{l}1.01 \\
3.98 \\
1.21 \\
6.82 \\
8.44 \\
3.71 \\
0.64\end{array}$ & $\begin{array}{r}0.96 \\
23.60 \\
2.55 \\
41.51 \\
28.48 \\
2.83 \\
0.15\end{array}$ & $\begin{array}{l}0.21 \\
2.45 \\
0.95 \\
7.50 \\
6.29 \\
1.39 \\
0.40\end{array}$ & $\begin{array}{r}1.26 \\
23.20 \\
3.78 \\
41.16 \\
26.01 \\
4.39 \\
0.23\end{array}$ & $\begin{array}{l}0.31 \\
2.36 \\
2.07 \\
4.92 \\
4.08 \\
2.04 \\
0.54\end{array}$ & $\begin{array}{l}\text { NS } \\
* \\
\text { NS } \\
* \\
\text { NS } \\
\text { NS } \\
\text { NS }\end{array}$ \\
\hline \multicolumn{9}{|l|}{ Phospholipid composition } \\
\hline 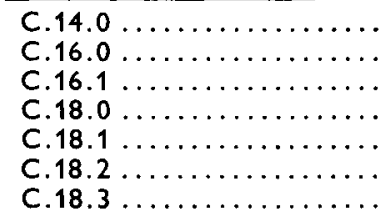 & $\begin{array}{l}\text { p. } 100\left(^{(6)}\right. \\
= \\
= \\
= \\
=\end{array}$ & $\begin{array}{r}0.24 \\
25.11 \\
1.81 \\
30.88 \\
23.58 \\
15.32 \\
3.11\end{array}$ & $\begin{array}{l}0.08 \\
3.08 \\
0.92 \\
6.33 \\
3.81 \\
3.86 \\
1.95\end{array}$ & $\begin{array}{r}0.23 \\
22.86 \\
2.99 \\
27.52 \\
25.63 \\
18.00 \\
2.77\end{array}$ & $\begin{array}{l}0.07 \\
2.25 \\
1.29 \\
2.58 \\
3.38 \\
2.13 \\
1.07\end{array}$ & $\begin{array}{r}0.27 \\
22.97 \\
2.50 \\
26.31 \\
24.57 \\
21.27 \\
2.15\end{array}$ & $\begin{array}{l}0.07 \\
1.95 \\
1.08 \\
4.63 \\
3.54 \\
3.16 \\
0.97\end{array}$ & $\begin{array}{c}* \\
\text { NS } \\
* \\
* \\
\text { NS } \\
* * \\
\text { NS }\end{array}$ \\
\hline \multicolumn{9}{|l|}{ Cholesteryl ester composition } \\
\hline 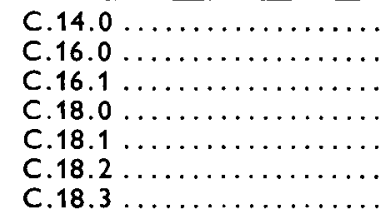 & $\begin{array}{l}\text { p. } 100(7) \\
= \\
= \\
= \\
=\end{array}$ & $\begin{array}{r}0.92 \\
17.72 \\
5.31 \\
3.52 \\
41.82 \\
29.75 \\
0.95\end{array}$ & $\begin{array}{l}0.69 \\
2.40 \\
1.92 \\
0.83 \\
4.51 \\
3.69 \\
0.53\end{array}$ & $\begin{array}{r}0.62 \\
13.99 \\
6.99 \\
4.39 \\
38.04 \\
34.51 \\
1.48\end{array}$ & $\begin{array}{l}0.17 \\
2.43 \\
1.66 \\
1.75 \\
6.02 \\
5.24 \\
1.67\end{array}$ & $\begin{array}{r}0.66 \\
13.58 \\
6.84 \\
2.61 \\
34.74 \\
40.33 \\
1.21\end{array}$ & $\begin{array}{l}0.15 \\
2.87 \\
1.23 \\
1.40 \\
6.59 \\
6.49 \\
0.40\end{array}$ & $\begin{array}{c}\text { NS } \\
* \\
* \\
* \\
* \\
* * * \\
\text { NS }\end{array}$ \\
\hline Blood insulin content & $\mu \mathrm{U} / \mathrm{ml}$ & 6.42 & 3.63 & 9.40 & 7.29 & 21.83 & 31.92 & NS \\
\hline
\end{tabular}

(1) Effect of diet : level of significance : ${ }^{* * *} \mathrm{P}<0.001,{ }^{* *} \mathrm{P}<0.01, * \mathrm{P}<0.05$, NS : not significant $\left({ }^{2}\right) \mathrm{g} \mathrm{p} .100 \mathrm{~g}$ of total blood lipids; $\left({ }^{3}\right) \mathrm{g} \mathrm{p} .100 \mathrm{~g}$ of total blood lipoproteins; ( $\left.{ }^{4}\right) \mathrm{g} \mathrm{p.} 100 \mathrm{~g}$ of free fatty acids $\left({ }^{5}\right) \mathrm{g} \mathrm{p.} 100 \mathrm{~g}$ of triglyceride fatty acids; $\left(^{6}\right) \mathrm{g} \mathrm{p} .100 \mathrm{~g}$ of phospholipid fatty acids ; (7) g p. $100 \mathrm{~g}$ of cholestero atty acids. 
12 and $140 \mathrm{~g}$ daily when fed 2 and 3 . During the 11 days of fasting, the mean loss of weights of the sheep was 15 p. 100 of live weight (16,11 and 18 p. 100 respectively, after diets 1,2 and 3). The mean daily loss of weight was $1367 \mathrm{~g} /$ animal/d during the first 2 days, $692 \mathrm{~g} /$ animal/d during days 3 to 6 and $561 \mathrm{~g} / \mathrm{animal} / \mathrm{d}$ during the last 3 days of the fasting period.

Blood composition during feeding periods. - The blood composition of sheep during the feeding periods is given in table 2 . Each value is the mean of results obtained for the 6 sheep during weeks 2, 3 and 4 of the experimental periods and therefore represents the mean of 18 individual values. The results obtained for variance analysis are also given in the table.

Plasma free fatty acid concentration was sharply reduced when passing from the roughage (dief 1) to the concentrate (diet 2) ration. This was further lowered with increasing intake level (diet 3).

Plasma lipid composition showed no significant change due to the diet.

Two strongly coloured strips only, corresponding to the electrophoretic motility of low density (LDL) and high density (HDL) lipoproteins were observed on lipoprotein electrophoretic separations. With the 3 rations, LDL represented about 40 p. 100 of total lipoprotein and HDL about 60 p. 100.

Fatty acid composition of the free fatty acid fraction showed some significant variation according to diet. On the hay diet, a higher percentage of oleic acid and a lower percentage of linoleic acid were obtained. Increasing intake level diet did not alter the fatty acid composition. The roughage/concentrate ratio also significantly influenced the fatty acid composition of the triglycerides. Stearic acid level showed a sharp increase when changing from diet 1 to diet 2 , while palmitic and oleic levels were reduced. The fatty acid composition of the phospholipids was also affected. The percentages of linoleic and palmitoleic acids were increased when passing from roughage to concentrate. The percentage of lineoleic acid was also enhanced when passing from low to high level of intake. In contrast, the level of stearic acid was reduced when passing from diet 1 to diet 3. The linoleic acid percentage of the cholesterylesters was sharply increased when passing from the roughage to the concentrate diet; when the intake level was further increased the level of linoleic acid was even higher. This was balanced by decreases in the concentrations of palmitic and oleic acids.

The mean plasma insulin content showed a small increase when changing from dief 1 to diet 2 but a very sharp increase with high intake level. Nevertheless the differences were not significant, due a very high variability in the results, especially those observed with diet 3.

Blood composition during fasting. - The changes in blood ketone body concentrations are given in figure 1 . In the beginning, the fast acetoacetate (AA) concentration was 2 to $4 \mathrm{mg} / \mathrm{l}$ and the $\beta$-hydroxybutyrate $(\mathrm{BHB})$ concentration was 20 to $45 \mathrm{mg} / \mathrm{l}$. The values decreased during the first day, then strongly increased until the fifth and sixth day $(10-15 \mathrm{mg} / \mathrm{l}$ acetoacetate and $50-100 \mathrm{mg} / \mathrm{l} \beta$-hydroxybutyrate), followed by a temporary stabilization. At the end of the test a nex increase was observed. The BHB/AA ratio had a mean value of 8 at the beginning of the trial, then decreased rapidly to reach a stable value of 5 in the fifth day. The increase of both ketone bodies was faster 


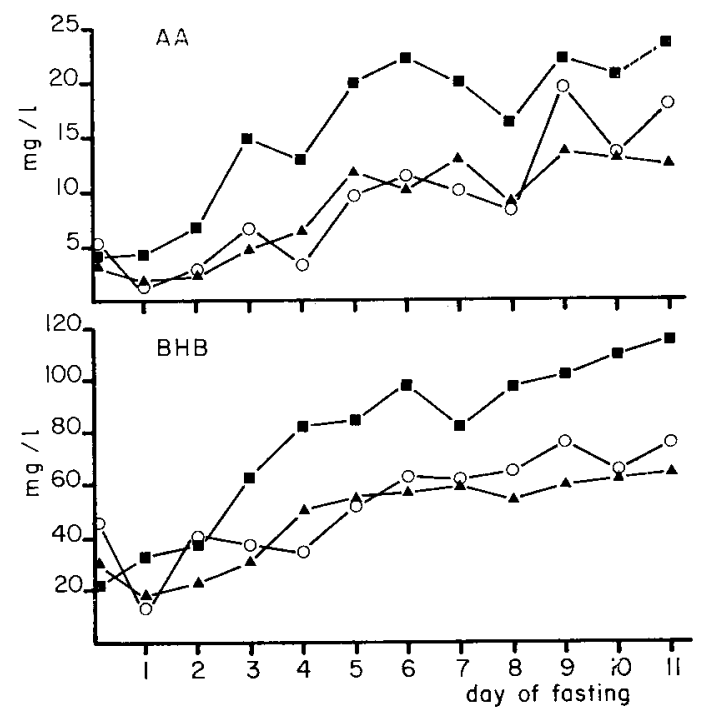

FIG. 1. - Changes in blood acefoacetafe (AA) and $\beta$-hydroxybutyrate (BHB) concentrations during fasting in sheep previously fed diets $1(-\square), 2(\Lambda-\Lambda)$ and $3(0-0)$.

for sheep previously fed with roughage (dief 1), resulting in high values from the third day onwards. On the other hand, comparable BHB/AA ratios were observed in the 3 groups of animals. The analysis of variance confirmed the influence of the time of fasting on blood ketone body concentration and on BHB/AA ratio $(P<0.001)$ and the effect of previous feeding on ketone body concentration $(P<0.01)$ and kinetics $(P<0.001$ for $B H B)$.

At the beginning of the test, mean glycemia was $51.8 \pm 5.2 \mathrm{mg} / 100 \mathrm{ml}$; after 1 day it had reached a value of $40.2 \pm 3.7 \mathrm{mg} / \mathrm{ml}$, followed by a period of stabilization. A slight increase was observed after 5-6 days of fast. The analysis of variance showed a significant effect due to time of fasting, but no effect due to the diet before fasting.

The changes in plasma free fatty acid concentration are given in figure 2. Day-today fluctuations were observed for all animals but the levels increased strongly from the first day of the fast, stabilizing on the fifth day until the end of the test. The large differences observed between the groups, i. e. higher concentrations for sheep previously fed the roughage diet, were rapidly suppressed during fasting. Analysis of variance confirmed that the time of fasting had a highly significant effect $(P<0.001)$ on the kinetics of plasma free fatty acid concentration and that these kinetics were influenced $(P<0.01)$ by the kind of diet previously received.

In the beginning of the fast, mean plasma lipid composition was 17.6 p. 100 free fatty acids, 14.1 p. 100 triglycerides, 28.9 p. 100 phospholipids, 13.9 p. 100 free cholesterol and 25.5 p. 100 cholesteryl esters. Significant changes occurred during the first 5 days of fast : the level of the free fatty acids increased to 27 p. 100 , the levels of the triglycerides and the phospholipids decreased to 10 and 24 p. 100. Thereafter a stabilization was observed. Variance analysis showed no significant change for free cholesterol and cholesteryl esters. 


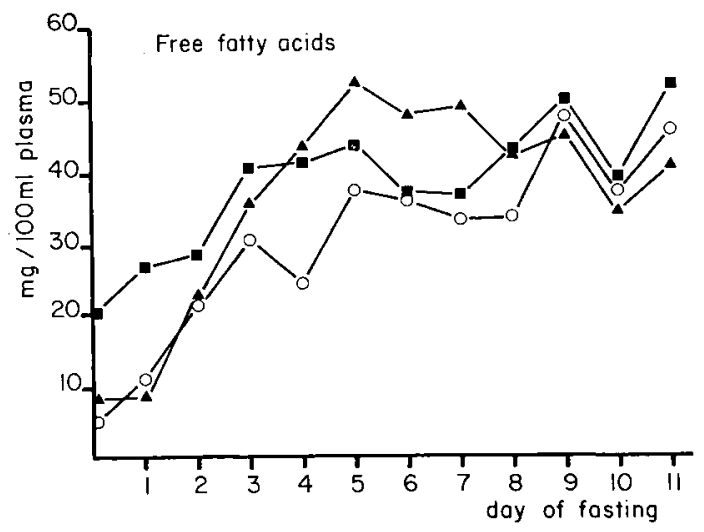

FIG. 2. - Changes in plasma free fatty acid concentration during fasting in sheep previously fed diets 1 (

The fatty acid composition of the blood during the feeding periods and thus before fasting are given in table 2 . Only the major changes observed during fasting are included here. Generally, fasting abolished the differences caused by previous feeding and changes occurred during the 5-6 first days of fasting and then stabilized. Some examples are given in figure 3 .
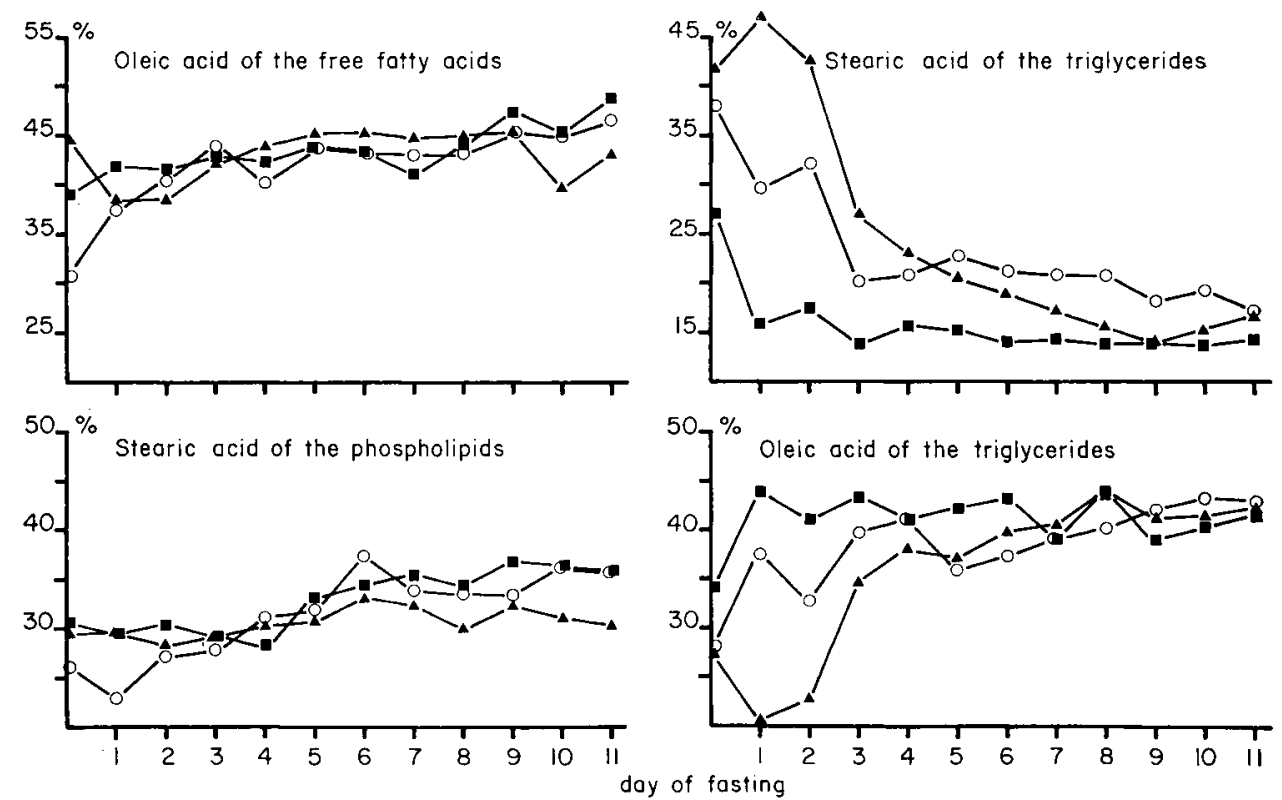

FIG. 3. - Some changes in fatty acid composition of blood lipids during fasting in sheep previously fed diets $1(\square-\infty), 2(\Delta-\infty)$ and $3(0-0)$. 
Fasting induced a significant increase in the proportion of oleic acid (fig. 3 ) in the free fatty acids and a decrease in the proportions of myristic and stearic acids.

The following changes were induced in the fatty acid composition of triglycerides: an increase in the concentration of oleic (fig. 3) and myristic (after all diets), palmitic (after diets 2 and 3) and linoleic (after diets 1 and 2) acids and a rapid decrease in the concentration of stearic acid (after all diets, fig. 3).

The fatty acid composition of phospholipids was similar for all the animals (low SD) so that in spite of apparently small differences as compared with the other lipid fractions, the differences observed for each acid during fasting were significant : the proportions of myristic, plamitic and stearic acids (fig. 3) increased, while those of palmitoleic, oleic and linoleic acids decreased.

The fatty acid composition of cholesteryl esters showed only significantly decreased proportions of myristic and palmitoleic acids during fasting.

The changes occuring in blood lipoprotein were similar for the three groups of animals. Fasting produced an increase in the proportion of the LDL (40 to $50 \mathrm{p}$. 100) and a decrease in the proportion of the HDL (60 to 50 p. 100). The value for the HDL/ $\mathrm{LDL}$ ratio was 1.5 at the beginning of the fasting period and decreased rapidly to reach a value of 1 on the fifth day. Although exhibiting a large variation, this value was maintained during the next 6 days. Analysis of variance confirmed the highly significant effect $(P<0.001)$ of the time of fasting on the lipoprotein distribution and the lack of influence of the previous diet.

The changes in plasma insulin concentration during fasting are given in figure 4. In the April 16 samples, that is after $1 \mathrm{~h} 30$ of feeding, the respective insulin concentrations were $22.7 \mu \mathrm{U} / \mathrm{ml}$ (diet $1,218 \mathrm{~g}$ roughage consumed), $120.0 \mu \mathrm{U} / \mathrm{ml}$ (diet $2,50 \mathrm{~g}$ roughage and $600 \mathrm{~g}$ concentrate consumed) and $88.6 \mu \mathrm{U} / \mathrm{ml}$ (diet 3, $241 \mathrm{~g}$ concentrate consumed). On day later the general mean was $9.8 \pm 5.9 \mu \mathrm{U} / \mathrm{ml}$ and from the 2 nd day on, a mean value below $9 \mu \mathrm{U} / \mathrm{ml}$ was maintained. Taking into account the results

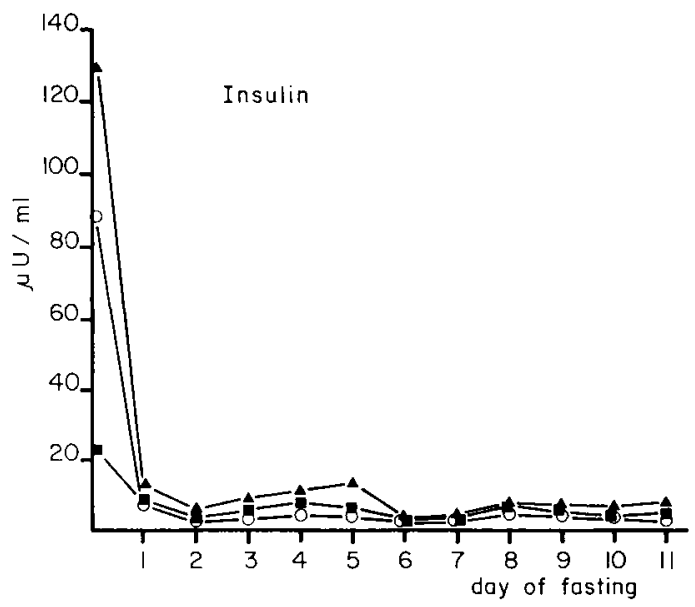

FIG. 4. - Changes in plasma insulin concentration during fasting in sheep previously fed diets 1 (-), 2 (4-1) and 3 (0-0). 
of April 16, the analysis of variance confirmed this highly significant effect of the time of fasting on insulinemia $(P<0.001)$; ortherwise the effects of the time of fasting and of the previous diet on insulin levels were not significant.

\section{Discussion.}

During the experimental feeding periods the free fatty acid concentration decreased when passing from diet 1 (roughage, intake level 0.6) to diet 2 (86 p. 100 concentrate, intake level 1) and to diet 3 (89 p. 100 concentrate, intake level 2.3). This change was inversely related to the fat intake (respectively 11,22 and $52 \mathrm{~g}$ daily) and also to the energy intake level. When passing from a low roughage diet $(0.6$ time-energy-maintenance requirements) to a roughage-concentrate diet just covering the maintenance requirements, the free fatty acid concentration decreased and a further decrease was observed with a high energy level ( 2.3 times the maintenance requirements). These changes can in part be explained by the differences in plasma insulin concentrations (increase from diet 1 to diet 3 ) which probably induced differences in the level of lipolysis and lipogenesis (body weight changes were respectively - 71, +12 and $+140 \mathrm{~g}$ /animal).

As has previously been shown by Leat, Kubasek and Butress (1976) and Noble ef al. (1977) there were two main lipoproteins (HDL and LDL) in the blood of the sheep. Their ratio was not influenced by feeding. The concentrations of chylomicrons and VLDL were negligeable.

The fatty acid distribution within the plasma lipids during feeding was similar to that obtained with a control diet by Noble ef al. (1977). This distribution varied with the nature of food, and an increase in the intake level resulted principally in an increase in the proportion of linoleic acid in the phospholipids and cholesteryl esters. This can be related to the observation of Lindsay and Leat (1977) : an enrichment of blood levels of linoleic acid results in its incorporation into the phospholipids and cholesteryl esters rather than its use for metabolic purpose.

During the first days of fasting extensive changes occur in the blood composition. The same changes were observed in previous experiments (Bouchat, Doizé and Paquay, 1980), where the patterns of fecal and urinary nitrogen losses where also studied. The same conclusions can thus be drawn : with the disturbance of the energy supply through fasting, there is a progressive mobilization of the lipid reserves and an increased transformation of liberated fatty acids into ketone bodies. For cerlain organs (particularly the brain and kidneys), these provide a better source of energy than the fatty acids. However the mobilization of fat tissue and the increased production of ketone bodies need a few days to stabilize. The immediately available labile protein reserve seemed to be the intermediary source of energy and to serve as a precursor of neoglucogenesis in order to avoid a drop in glycemia. In our previous paper (Bouchat, Doizé and Paquay, 1980) we reported some recent observations to support these conclusions. Other new supporting conclusions can be provided. A glucose injection in fasted rats decreases the fatty acid mobilization (Coimbra, Gross and Migliorini, 1979). The adipose tissue basal glucose metabolism declines with fasting, while the rate of 
lipolysis increases (Owens ef al., 1979). There is an increased use of ketone bodies by the jejunum epithelial cells in fasted rats (Hanson and Parsons, 1978). Compared with dieting, ketogenic food decreases by some 2.5 to 5 times the body nitrogen losses in man (Anonymous, 1978). However, it should be pointed out that Balasse (1979) explains the kinetics of ketonemia during fasting by an inhibitory influence on the rate of ketogenesis.

In fasting the initial changes in blood composition appear to be the result of changes in the blood insulin. As Trenkle (1978) we noted an increment of insulinemia directly after feeding. Twenty-four hours later very low values were obtained. Such a decrease has also been observed by others working on ruminants (Athanasiou and Phillips, 1978 ; Bassett, 1974 ; Kolb, 1977 ; Trenkle, 1978) ; it can be explained by a slower insulin release from the pancreas (Lipson et al., 1979) and by a higher clearance of blood insulin by the liver (Striffler and Curry, 1979). The decrease of insulinemia induces a fat mobilization, a lowered transport of blood glucose to tissues and a change in liver metabolism of fatty acids from the synthesis of triglycerides to the synthesis of ketone bodies (Witters and Trasko, 1979).

During fasting, in the present experiment, a rapid decrease of the HDL/LDL ratio was seen. This change may be related to a diminished synthesis of the HDL in the intestinal wall and to a decreased hydrolysis of the LDL triglycerides by adipose tissue lipoprotein lipase (Streja, Marliss and Steiner, 1977).

The changes observed in the fatty acid composition of the blood lipids during fasting agree with our previous observations (Bouchat, Doizé and Paquay, 1980) and may be explained by the conclusions of Lindsay and Leat (1977), that is, in fasted sheep, palmitic, stearic and oleic acids are preferently mobilized. In rats, however, Demarne ef al. (1977) came to the conclusion that all the longchain fatty acids are catabolized in the same way during fasting.

In our previous paper (Bouchat, Doizé and Paquay, 1980), we concluded that the level of most of the blood constituents tend to stabilize after 5 to 6 days of fasting. Except for ketone bodies and glucose and the observations of Baird ef al. (1979) in cow and Balasse (1979) in man, the present results confirm such a conclusion.

As a result of observations by Balasse and Neef (1975) in man and by Bates and Linn (1976) in rat, the rate of ketogenesis which is regulated by the levels of the ketone bodies themselves may well be dependent on the body condition of the sheep. During the present experiment, in animals of medium body condition (mean $55 \mathrm{~kg}$ live-weight), a new increase of ketonemia occurred after 10 days of fasting. During the previous investigation (Bouchat, Doizé and Paquay, 1980), fat sheep (more than $85 \mathrm{~kg}$ ) showed a stability in blood ketone concentration after 5-6 days, whereas in sheep of medium body condition (40-60 kg), kefonemia increased during the 8 days of the test. The stability of the plasma free fatty acid concentration after 5-6 days of the fast could be attributed to the reduction of lipolysis induced by an accumulation of free fatty acids in plasma (Burns, 1978). The increased glycemia occurring after an initial decrease and a period of stabilization was also observed by Bowden (1973) and Athanasiou and Phillips (1978) in cows. The re-establishment of glycemia may well be attributed to the decreased use of blood glucose by the heart (Daniel, Love and Pratt, 1978). the digestive tract (Hanson and Parsons, 1978 ; Prior and Jacobson, 1979) and the adipose tissue (Olefsky, 1976). 
The nature (roughage/concentrate ratio) and level of food given during pre-fasting had little direct effect on the blood composition during fasting. After a rapid disappearance of initially observed differences, the only difference was a faster increment of blood ketone bodies in the sheep previously fed the roughage diet. In contrast the fattening state induced by the diet had longer term influence on blood composition during fasting. In the previous experiment (Bouchat, Doizé and Paquay, 1980), there was a faster body fat mobilization in the fat sheep. In the fat state in man (Arner, Engfeldt and Ostman, 1979) and in rat (MacDonald, Rothwell and Stock, 1979) there is also faster lipid mobilization. These observations could be related to a diminished insulin release in the obese animal as opposed to the lean animal during fasting (BeloffChain, Bogdanovic and Cawthorne, 1977).

Reçu en mai 1980.

Accepté en septembre 1980.

Acknowledgments. - This work was supported by the Institut pour l'Encouragement de la Recherche Scientifique dans l'Industrie et l'Agriculture (IRSIA), rue de Crayer, 1050 Brussels, Belgium.

Résumé. Dans le but d'étudier les effets de la nature de la ration, du niveau d'ingestion et d'un jeône prolongé sur la composition du sang, 6 brebis Suffolk adultes ont reçu successivement suivant la méthode des doubles carrés latins et pendant des périodes de 4 semaines, 3 rations destinées à comparer deux niveaux d'ingestion alimentaire (niveaux 1 ef 3 ) et 2 rapports fourrages/concentrés (100 et 14 p. 100 de fourrages). Les 6 animaux ont par la suite été mis à jeun pendant 11 jours.

La concentration en acides gras libres du sang diminue lors du passage de la ration constituée de foin à celle riche en concentrés et elle subit une diminution supplémentaire lors de l'augmentation du niveau d'ingestion. La composition des lipides et des lipoprotéines sanguins n'est pas influencée par la nature de la ration. L'apport de concentrés en remplacement de foin provoque principalement une augmentation des proportions d'acide stéarique dans les acides gras libres et les triglycérides et d'acide linoléique dans les phospholipides et les esters de cholestérol, une diminution de l'acide oléique dans les acides gras libres ef de l'acide oléique ef de l'acide palmitique dans les triglycérides ef les esters de cholestérol. Une hausse supplémentaire de la proportion d'acide linoléique dans les phospholipides et les esters de cholestérol se produit lors de l'augmentation de l'ingestion des concentrés. La teneur en insuline du sang paraît être plus élevée avec les concentrés, surtout s'ils sont distribués abondamment.

La mise à jeun prolongée provoque pour tous les constituants une disparition rapide des différences dues à l'alimentation préalable. Après une diminution le premier jour, la concentration des corps cétoniques augmente et le rapport $\beta$-hydroxybutyrate/acétoacétate décroît. La glycémie diminue le premier jour puis se stabilise, la concentration en acides gras libres augmente fortement dès le premier jour et leur proportion s'élève dans les lipides totaux. Dans les acides gras libres et les triglycérides, une augmentation de la proportion de l'acide oléique est compensée par une réduction de celle des acides saturés. Un appauvrissement en acides polyinsaturés dans les phospholipides et les esters de cholestérol est compensé par un enrichissement en acides saturés et en acide oléique. Le rapport entre les lipoprotéines à haute densité et les lipoprotéines à faible densité diminue et la concentration en insuline subit une chute conséquente dès le premier jour.

La composition du sang montre une grande stabilité après 5 ou 6 jours de jeône exception faite pour les corps cétoniques (nouvelle augmentation après une dizaine de jours) ef le glucose (faible augmentation après $5-6$ jours). 
Lorsqu'elle ne modifie pas l'état d'engraissement de l'animal, la nature de la ration distribuée avant la mise à jeun, $n$ 'a, après la disparition des différences initiales, pratiquement aucune influence sur l'évolution de la composition du sang pendant la privation de nourriture. Par contre, si l'animal est gras plutôt que maigre au moment de la mise à jeun, des modifications durables de cette composition sont observées.

\section{References}

ANONYMOUS, 1978. The nature of weight loss during short-term dieting. Nutr. Rev., 36, 72-74. ARNER P., ENGFELDT P., OSTMAN J., 1979. Relationship between lipolysis, cyclic AMP, and fat-cell size in human adipose tissue during fasting and in diabetes mellifus. Metabolism, 28, 198-209.

ATHANASIOU V. N., PHILLIPS R. W., 1978. Effect of fasting on plasma metabolites and hormones in lactating dairy cows. Am. J. vet. Res., 39, 957-960.

BAIRD G. D., HEITZMAN R. J., REID I. M., SYMONDS H. W., LOMAX M. A., 1979. Effects of food deprivation of ketonemia, ketogenesis and hepatic intermediary metabolism in the nonlactating dairy cow. Biochem. J., 178, 35-44.

BALASSE E. O., 1979. Kinetics of ketone body metabolism in fasting humans. Metabolism, 28, 41-50.

BALASSE E. O., NEEF M. A., 1975. Inhibition of ketogenesis by ketone bodies in fasting humans. Metabolism, 24, 999-1007.

BASSETT J. M., 1974. Diurnal patterns of plasma insulin, growth hormone, corticosteroid and metabolite concentrations in fed and fasted sheep. Austr. J. biol. Sci., 27, 167-182.

BATES M. W., LINN L. C., 1976. Blood D-3-hydroxybutyrafe and the regulation of plasma concentrations of free fatty acids in the fasted rat. Metabolism, 25, 685-695.

BELOFF-CHAIN A., BOGDANOVIC S., CAWTHORNE M. A., 1977. Influence of fasting on basal and pituitary-stimulated insulin secretion from perfused pancreatic islets of lean and obese mice. FEBS Letters, 76, 290-293.

BOUCHAT J. CI., DOIZÉ F., PAQUAY R., 1980. Effects of fasting on blood composition and nitrogen losses in the adult sheep depending on previous diet and body weight. Reprod. Nuir. Dévelop., 20, 77-92.

BOWDEN D. M., 1973. Effects of postfeeding interval on blood constituents related to energy metabolism in nonpregnant Angus and Hereford heifers. Can. J. anim. Sci., 53, 641-646.

BURNS T. W., LANGLEY P. E., TERRY B. E., 1978. The role of free fatty acids in the regulation of lipolysis by human adipose tissue cells. Metabolism, 27, 1755-1762.

COIMBRA C. C., GROSS J. L., MIGLIORINI R. H., 1979. Intraventricular 2-deoxyglucose, glucose, insulin and free fatty acid mobilization. Amer. J. Physiol., 5, E317-322.

DANIEL P. M., LOVE E. A., PRATT O. E., 1978. Insulin and the transport of glucose into the heart in vivo during fasting. J. Physiol., 276, 58P-59P.

DEMARNE Y., TOURE M., FLANZY J., LECOURTIER M. J., 1977. Relationships between fatty acid composition of body lipids and lipid mobilization in rat. I. A study of carcass lipids. Ann. Biol. anim. Biochim. Biophys., 17, 249-258.

DOIZÉ F., BOUCHAT J. CI., PAQUAY R., 1979. Diurnal changes in blood ketone bodies, glucose and lipids according to energy intake in adult sheep. Ann. Biol. anim. Bioch. Biophys., 19, 393-404.

HANSON P. J., PARSONS D. S., 1978. Factors affecting the utilization of ketone bodies and other substrates by rat jejunum : effects of fasting and of diabetes. J. Physiol., 278, 55-67.

KOLB E., 1977. Neuere Erkenntnisse zur Bedeutung des Insulins für die Produktionsleistungen und für die Stoffwechselregulation bei Wiederkäuern sowie zum Verhalten bei Stoffwechselkrankheiten (Hypokalzämie, Ketose) und Produktionsstörungen (Milchfett-Mangelsyndrom). Monatsh Veterinärmed., 5, 190-195.

LEAT W. M. F., KUBASEK F. O. T., BUTRESS N., 1976. Plasma lipoproteins of lambs and sheep. Quart. J. exper. Physiol., 61, 193-202.

LINDSAY D. B., LEAT W. M. F., 1977. Oxidation and metabolism of linoleic acid in fed and fasted sheep. J. ogric. Sci., Cambr., 89, 215-221. 
LIPSON L. G., SIEGEL E., WOLHEIM C. B., SHARP W. G., 1979. Insulin release during fasting. Studies on adenylate cyclase, phosphodiesterase, protein kinase, and phosphoprotein phosphatase in isolated islets of Langerhans of the rat. Endocrinology, 105, 702-707.

MACDONALD I. A., ROTHWELL N. J., STOCK M. J., 1979. Lipolytic and lipogenic activities of adipose tissue during spontaneous fat depletion and repletion. Proc. Nutr. Soc., 35, 129A-130A.

MORGAN C. R., LAZAROW A., 1963. Immunoassay of insulin : two antibody systems, Diabetes, 12, 115-126.

NOBLE R. P., 1968. Electrophorefic separation of plasma lipoproteins in agarose gel. J. Lipid. Res., 9, 693-700.

NOBLE R. C., VERNON R. G., CHRISTIE W. W., MOORE J. H., EVANS A. J., 1977. The effect of dietary fats on the plasma lipid composition of sheep. Lipids, 12, 5, 423-433.

OLEFSKY J. M., 1976. Effects of fasting on insulin binding, glucose transport, and glucose oxidation in isolated rat adipocyfes. Relationship between insulin receptors and insulin action. $\mathrm{J}$. clin. Invest., 58, 1450-1460.

OWENS J. L., THOMPSON D., SHAH N., DIGIROLAMO M., 1979. Effects of fasting and refeeding in the rat on adipocyte metabolic functions and response to insulin. J. Nutr., 109, 1584-1591.

PRIOR R. L., JACOBSON J. J., 1979. Effects of fasting and refeeding and intravenous glucose infusion on in vitro lipogenesis in bovine adipose tissue. J. Nutr., 109, 1279-1284.

STREJA D. A., MARLISS E. B., STEINER G., 1977. The effects of prolonged fasting on plasma triglyceride kinetics in man. Metabolism, 26, 505-516.

STRIFFLER J. S., CURRY D. L., 1979. Effect of fasting on insulin removal by liver of perfused liverpancreas. Amer. J. Physiol., 237, E349-355.

TRENKLE A., 1978. Relation of hormonal variations to nutritional studies and metabolism of ruminants. J. Dairy Sci., 61, 281-293.

WITTERS L. A., TRASKO C. S., 1979. Regulation of hepatic free fatty acid metabolism by glucagon and insulin. Amer. J. Physiol., 6, E23-29. 